\title{
Serum and salivary chemerin concentrations in patients with colorectal cancer and obesity
}

\author{
Stężenia chemeryny w surowicy i ślinie \\ u pacjentów z rakiem jelita grubego i towarzyszącą otyłością \\ Dariusz Waniczek1 (D) Elżbieta Świętochowska² (D) , Zbigniew Lorenc ${ }^{3}$ \\ 'Zakład Pielęgniarstwa Chirurgicznego i Propedeutyki Chirurgii, Wydział Nauk o Zdrowiu w Katowicach, \\ Śląski Uniwersytet Medyczny w Katowicach \\ ${ }^{2}$ Katedra i Zakład Biologii Medycznej i Molekularnej, Wydział Nauk Medycznych w Zabrzu, \\ Śląsi Uniwersytet Medyczny w Katowicach \\ ${ }^{3}$ Katedra i Oddział Kliniczny Chirurgii Ogólnej, Kolorektalnej i Urazów Wielonarządowych, \\ Wydział Nauk o Zdrowiu w Katowicach, Śląski Uniwersytet Medyczny w Katowicach
}

\begin{abstract}
INTRODUCTION: Chemerin is an adipokine, whose pro-inflammatory and carcinogenesis-related properties have recently been emphasized. The aim of this study was to examine the concentrations of chemerin in the serum and saliva of healthy subjects and patients with colorectal cancer (CRC) in II and III stage of TNM (tumor, node, metastasis) classification as well as to assess the relationship between the results and the clinical and pathological parameters.

MATERIAL AND METHODS: 52 persons were qualified to the study, divided into two equal groups - control and study with cancer in stage II N0 and in stage III N+ according to TNM classification. Inside the groups, subgroups of persons with normal body weight $18.5 \leq \mathrm{BMI}<25$ and obese and overweight persons with a BMI $\geq 25$ were distinguished. Serum and saliva chemerin concentrations were determined by immunoenzymatic methods.

RESULTS: The median concentrations of chemerin were significantly higher in the study group as compared to the control group both in serum $(384.36 \mathrm{ng} / \mathrm{ml}$ vs. $170.53 \mathrm{ng} / \mathrm{ml})$ and saliva $(15.45 \mathrm{ng} / \mathrm{ml}$ vs. $4.57 \mathrm{ng} / \mathrm{ml} ; \mathrm{p}<0.0001)$. In the subgroups with a BMI above and below 25, we found no significant differences in the concentrations of chemerin either group. There were no significant differences in the levels of chemerin in the serum or saliva between stage II and III stage of TNM $(p=0.82$ and $p=0.52)$.

CONCLUSIONS: The assessment of serum and saliva chemerin concentrations in patients with CRC suggests that chemerin may be a valuable biomarker for early diagnosis of CRC. The influence of BMI on the results seems to be insignificant in patients with CRC. It seems that in some cases an easily accepted saliva test can replace a serum one.
\end{abstract}

\section{KEY WORDS}

obesity, colorectal cancer, chemerin, cancer biomarker

\begin{tabular}{l}
\hline Received: $16.10 .2020 \quad$ Revised: 22.10.2020 Accepted: 24.10.2020 Published online: 28.02 .2021 \\
Address for correspondence: dr hab. n. med. Dariusz Waniczek, Zakład Pielęgniarstwa Chirurgicznego i Propedeutyki Chirurgii, Wydział Nauk o Zdrowiu \\
w Katowicach, Ślaski Uniwersytet Medyczny w Katowicach, ul. Żeromskiego 7, 41-902 Bytom, Polska, tel. +48 32 396 32 03, e-mail: dwaniczek@sum.edu.pl
\end{tabular}




\section{STRESZCZENIE}

WSTĘP: Chemeryna jest hormonem wydzielanym przez adipocyty. W ostatnim czasie zwraca się uwagę na jej właściwości prozapalne i związane z karcynogenezą. Celem pracy było zbadanie stężeń chemeryny w surowicy i ślinie osób zdrowych oraz chorych z rakiem jelita grubego (RJG) w II i III stopniu zawansowania według klasyfikacji TNM (tumor, node, metastasis), a także ocena związku uzyskanych wartości z otyłością oraz wybranymi parametrami kliniczno-patologicznymi.

MATERIAŁ I METODY: Do badania zakwalifikowano 52 osoby, które podzielono na dwie równe grupy - kontrolną i badaną z nowotworem w II stopniu zaawansowania z cechą N0 oraz w III stopniu z cechą N+ według klasyfikacji TNM. Wewnątrz grup wyróżniono podgrupy osób o prawidłowej masie ciała $(18,5 \leq \mathrm{BMI}<25)$ oraz osoby otyłe i z nadwagą (BMI $\geq 25$ ). Stężenia chemeryny w surowicy i ślinie oznaczano metodami immunoenzymatycznymi.

WYNIKI: Mediany stężeń chemeryny były istotnie wyższe w grupie badanej w porównaniu z grupą kontrolną, zarówno W surowicy $(384,36 \mathrm{ng} / \mathrm{ml}$ wobec $170,53 \mathrm{ng} / \mathrm{ml})$, jak i ślinie $(15,45 \mathrm{ng} / \mathrm{ml}$ wobec $4,57 \mathrm{ng} / \mathrm{ml} ; \mathrm{p}<0,0001)$. W żadnej grupie w podgrupach z BMI powyżej i poniżej 25 nie znaleziono istotnych różnic w stężeniach badanej adipokininy. Nie odnotowano również istotnych różnic stężeń chemeryny w surowicy i ślinie między nowotworami w II i III stopniu zaawansowania TNM $(\mathrm{p}=0,82 \mathrm{i} \mathrm{p}=0,52)$.

WNIOSKI: Ocena stężeń chemeryny w surowicy i ślinie u pacjentów z RJG sugeruje, że badana adipokina może być cennym biomarkerem wczesnej diagnostyki tego nowotworu. Wpływ BMI na uzyskane wyniki stężeń w surowicy i ślinie wydaje się nieistotny u chorych z RJG. Wydaje się, że w pewnych przypadkach łatwo akceptowane przez chorych badanie śliny może zastąpić badanie surowicy.

\section{SŁOWA KLUCZOWE \\ rak jelita grubego, otyłość, biomarker nowotworowy, chemeryna}

\section{INTRODUCTION}

Colorectal cancer (CRC) is the most common gastrointestinal malignant tumour; it is the second and third most common malignancy in men and women, respectively [1]. Its development is associated with age and an unhealthy lifestyle, and in some cases with specific genetic factors. The risk factors also include inflammatory bowel disease (IBD).

Obesity is a state of excess body fat. The increase in prosperity, changes concerning working life, and new habits in eating and spending free time have also led to a growing obesity problem in Poland. An excessively calorific diet, apart from the process of population ageing, are the main reasons for the constant increase in the number of CRC cases. Obesity is also accompanied by an increase in cancer-related mortality [2,3].

Fat, apart from storing energy, acts as an endocrine organ, synthesising and releasing many biologically active substances into circulation. In recent years, the contribution of fat to carcinogenesis has been intensively studied. Adipokines are active substances produced by adipocyte fat cells. Chemerin is one of the rather poorly known adipokines, with multi-directional effects. It affects, among others, the immune system, energy homeostasis, fat condition and carbohydrate metabolism regulation, blood pressure, increased insulin resistance, angiogenesis, etc. $[4,5,6]$. Recently, there have been papers indicating chemerin as a promising CRC marker $[7,8,9]$. In addition, other studies have also shown elevated serum chemerin concentrations in other types of cancer $[5,10,11]$. Elevated serum chemerin has also been reported in many inflammatory diseases, including IBD $[7,12]$.
With the increasing incidence of $\mathrm{CRC}$, there is an urgent need to search for new diagnostic, prognostic and predictive factors based on which new diagnostic tests can be developed for early diagnosis, the correct prognosis of the course as well as the possibility of proposing optimal, individualised treatment to the patient. This study aims to investigate the serum and saliva chemerin concentrations in obese and overweight patients in addition to patients with normal body weight with stage II (pT3-4N0M0) and stage III CRC (pT1$-4 \mathrm{~N}+\mathrm{M} 0$ ) according to the TNM (tumor, node, metastasis) classification, to compare the above results with chemerin concentrations in healthy subjects, and then evaluate the correlation of these results with selected anthropometric traits, age, selected laboratory tests and pathological features of this cancer.

\section{MATERIAL AND METHODS}

The study included two groups of patients $(n=52)$ aged over 50 . The study group (B) consisted of patients operated on in the general surgery ward $(n=26)$ with invasive, histopathologically confirmed $\mathrm{CRC}$, with no metastases to the liver in preoperative imaging, confirmed with an intraoperative examination (15 women, 11 men; mean age 67.4 (51-91)). The control group (K) included healthy outpatient volunteers $(n=26)$ with no pathological lesions revealed during colonoscopy, no history of cancer or serious inflammatory diseases (15 women, 11 men; mean age $64(50-83)$ ). In group K, patients with chronic diseases (except diabetes and hypertension) were excluded from the study. Patients previously treated for other types of cancer and IBD 
were also excluded. The age of the subjects, their sex, including the percentage distribution, median in addition to the first and third quartiles, are shown in Table I. Within groups B and $\mathrm{K}$, subgroups of patients with normal body weight $(18.5 \leq \mathrm{BMI}<25)$ as well as obese and overweight patients (BMI $\geq 25)$ were distinguished. The study was carried out with prior approval of the Ethics Committee, No. KW/0022/KBI/42/14/16/18. All the patients agreed to participate in the study.

\begin{tabular}{|c|c|c|c|c|c|c|}
\hline Group & Sex & $\mathrm{N}$-number & $\%$ & Median & Q1 & Q3 \\
\hline \multirow{2}{*}{ K } & M & 11 & 42.31 & 61.00 & 54.00 & 70.00 \\
\hline & $\mathrm{F}$ & 15 & 57.69 & 67.00 & 57.00 & 72.00 \\
\hline \multirow{2}{*}{ B } & $\mathrm{F}$ & 15 & 57.69 & 70.00 & 67.00 & 76.00 \\
\hline & M & 11 & 42.31 & 65.00 & 57.00 & 73.00 \\
\hline
\end{tabular}

The analysis of groups $\mathrm{K}$ and B was based on clinical, laboratory and imaging studies. The anthropometric characteristics, age and laboratory results of groups $\mathrm{K}$ and $\mathrm{B}$ as well as the comparison of the groups, are presented in Table II. The pathological characteristics of group B are presented in Table III.

\section{Analytical methods}

Before surgery or in connection with the necessary laboratory tests, $5 \mathrm{ml}$ of blood was collected from the basilic vein of each studied patient. Then, after coagulation,centrifugation and removal of the clot, the obtained sera were collected for further assays. The collected material was stored at $-80^{\circ} \mathrm{C}$.

Salivette swabs were used for saliva collection. The patients refrained from eating and drinking for 20 minutes before the collection. Then, after rinsing the mouth, they intensively chewed the swab for about three minutes. Next, the swab was closed and centrifuged as standard. The collected material was stored at $-80^{\circ} \mathrm{C}$.

\section{Determination of chemerin concentration}

The concentrations of chemerin in the blood serum and saliva were determined using the immunoenzymatic method with a Bio-Vendor LLC test (BioVendor

Table II. Age, anthropometric characteristics, results of basic laboratory serum tests in groups $\mathrm{K}$ and $\mathrm{B}$ with group comparison Tabela II. Wiek, charakterystyka antropometryczna, wyniki podstawowych badań laboratoryjnych w surowicy grup K i B z porównaniem grup

\begin{tabular}{|c|c|c|c|c|c|c|c|}
\hline \multirow{2}{*}{ Variable } & \multicolumn{3}{|c|}{ K } & \multicolumn{3}{|c|}{ B } & \multirow{2}{*}{$p$} \\
\hline & Median & Q1 & Q3 & Median & Q1 & Q3 & \\
\hline Age (years) & 64.00 & 57.00 & 71.00 & 68.50 & 61.00 & 74.00 & 0.19 \\
\hline Height (cm) & 170.00 & 164.00 & 174.00 & 167.00 & 161.00 & 176.00 & 0.48 \\
\hline Body weight $(\mathrm{kg})$ & 73.00 & 68.00 & 80.00 & 74.50 & 65.00 & 85.00 & 0.86 \\
\hline BMI $\left(\mathrm{kg} / \mathrm{cm}^{2}\right)$ & 24.89 & 23.26 & 27.89 & 25.89 & 23.26 & 28.73 & 0.72 \\
\hline Haemoglobin (g/dl) & 14.15 & 13.60 & 15.10 & 11.90 & 10.50 & 12.80 & 0.00 \\
\hline WBC (thousand/ $\mu \mathrm{l}$ ) & 7.39 & 6.10 & 8.71 & 8.15 & 6.35 & 9.90 & 0.15 \\
\hline Neutrophils (thousands/ $\mathrm{\mu l}$ ) & 3.96 & 3.18 & 5.00 & 6.30 & 4.83 & 7.79 & 0.00 \\
\hline 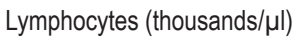 & 1.82 & 1.40 & 2.90 & 1.39 & 1.01 & 1.75 & 0.01 \\
\hline PLT (thousands/ $\mu \mathrm{l}$ ) & 271.00 & 236.00 & 347.00 & 305.50 & 213.00 & 418.10 & 0.76 \\
\hline CEA (ng/ml) & 2.35 & 1.40 & 3.60 & 3.70 & 2.55 & 15.80 & 0.01 \\
\hline NLR & 2.17 & 1.66 & 2.55 & 4.20 & 2.92 & 5.83 & 0.00 \\
\hline PLR & 147.80 & 110.86 & 187.80 & 196.94 & 168.00 & 312.50 & 0.02 \\
\hline
\end{tabular}

Table III. Pathological characteristics of group B Tabela III. Charakterystyka patologiczna grupy B

\begin{tabular}{|c|c|}
\hline Feature & Value \\
\hline Cancer site (laterality) & $\begin{array}{l}\text { Right colon: } 14:(53.85 \%) \\
\text { Left colon and rectum: } 12:(46.12 \%)\end{array}$ \\
\hline $\mathrm{T}$ - primary tumour size & T1: 0; T2: 3 (11.54\%); T3: 19 (73.08\%); T4: 4 (15.38\%) \\
\hline $\mathrm{N}$ - regional lymph node status & N0: $10(38.46 \%) ; \mathrm{N} 1: 6(23.08 \%) ; \mathrm{N} 2: 10(38.46 \%)$ \\
\hline $\mathrm{M}$ - metastases & M0: $26(100 \%) ;$ M1: 0 \\
\hline TNM classification & IIA: 8 (30.77\%); IIB: 2 (7.69\%); IIIA: 2 (7.69\%); IIIB: 10 (38.46\%); IIIC: 4 (15.38\%) \\
\hline Astler-Coller classification & B2: 8 (30.77\%); B3: 1 (3.85\%); C1: 3 (11.54\%); C2: 14 (53.85\%) \\
\hline
\end{tabular}


- Laboratorní medicína a.s. Czech Republic) cat. RD 191136200R, according to the manufacturer's instructions. To determine the concentrations in the tested samples, a calibration curve was prepared using the standards included in the kit.

Absorbance readings were taken with a BIO-TEK INC. $\mu$ Quant Universal Microplate Spectrophotometer (Bio-Tek World Headquarters, California, USA) at $450 / 630 \mathrm{~nm}$ and the results were processed with the KCJunior computer program (Bio-Tek, USA). The sensitivity of the set was $0.01 \mathrm{ng} / \mathrm{ml}$, the intra-assay error was $5.1 \%$, and the extra-assay error was $8.3 \%$.

\section{Statistical methods}

The obtained results were analysed statistically. The distribution of the quantitative variables was assessed using the Shapiro-Wilk test. The data was presented as a median with interquartile spacing due to the abnormal distribution of the examined variables. The Mann-Whitney U test was used to compare variables between groups. The links between the variables were evaluated using Spearman's rank correlation coefficient. The statistical analysis was conducted using STATISTICA 13 (Tibco software). Values of $\mathrm{p}<0.05$ were regarded as statistically significant.

\section{RESULTS}

The studied groups $\mathrm{B}$ and $\mathrm{K}$ were homogeneous in terms of age, basic anthropometric parameters (height, body weight and BMI). Significant differences were observed in part of the laboratory tests (haemoglobin concentration, CEA, neutrophil count, lymphocyte count, NLR and PLR) - see Table II.

Of the 26 patients in group B, $14(53.85 \%)$ had a tumour located in the right colon and $12(46.12 \%)$ in the left colon or rectum. In group B, according to TNM classification, 10 patients $(38.46 \%)$ had stage II, and 16 (51.54\%) stage III CRC (Table III). The median concentrations of chemerin were significantly higher in group $\mathrm{B}$ compared to group $\mathrm{K}$ both in the serum $(384.36 \mathrm{ng} / \mathrm{ml}$ versus $170.53 \mathrm{ng} / \mathrm{ml})$ and saliva ( $15.45 \mathrm{ng} / \mathrm{ml}$ versus $4.57 \mathrm{ng} / \mathrm{ml} ; \mathrm{p}<0.0001)$, as shown in Table IV.

No differences were found in the subgroups of groups $\mathrm{K}$ and $\mathrm{B}$ of patients with normal $\mathrm{BMI}<25$, overweight, and obese $\mathrm{BMI} \geq 25$ (Tables $\mathrm{Va}, \mathrm{Vb}$ ).

In the analysed pathological parameters, no statistically significant difference was found between TNM stages II and III and the tumour site and serum and saliva chemerin concentrations. The results of the correlation analysis are summarised in Tables VIa and VIb.

\section{DISCUSSION}

Chemerin is one of the adipokines produced mainly by adipocytes, fat stromal cells, the liver and placenta. Its high expression has also been found in the lungs, pancreas, kidney, skin, skeletal muscles, adrenals, heart, thymus, and brain [3]. It is synthesised on chromosome 7, as a 163 amino acid prepropeptide, i.e. preprochemerin, transformed into inactive $18-\mathrm{kDa}$ prochemerin, then by proteases into an active $16-\mathrm{kDa}$ protein. Chemerin plays an important role in the processes of innate and acquired immunity, exerting pro-inflammatory effects $[12,14]$.

Our results showed significant differences in the concentration of chemerin, which were significantly lower in group $\mathrm{K}$ in comparison to the CRC patients in group $\mathrm{B}$, both in serum and saliva $(\mathrm{p}<0.0001)$. The median values of chemerin in serum and saliva were lower in group $\mathrm{K}$ compared to group B; in serum, it was $170.53 \mathrm{ng} / \mathrm{ml}$ versus $384.36 \mathrm{ng} / \mathrm{ml}$ and saliva $4.57 \mathrm{ng} / \mathrm{ml}$ versus $15.45 \mathrm{ng} / \mathrm{ml}$, respectively. This indicates the relevance of chemerin concentration determination as a diagnostic marker of CRC. Similar results concerning serum were found in other studies $[7,8,9]$. In a study on a large group of patients, Eichelmann et al. [9] demonstrated that higher concentrations of chemerin were associated with a higher risk of $\mathrm{CRC}$, with a risk factor of $\mathrm{HR}=1.81(95 \% \mathrm{CI}, 1.08-3.05 ; \mathrm{P}=0.007)$. In the study by Alkady et al. [8], a progressive increase in chemerin serum concentrations was observed along with tumour progression; the greatest difference was between TNM stages I and II $(275.2 \pm 58.7 \mathrm{ng} / \mathrm{ml}$ versus $365 \pm$ $34.6 \mathrm{ng} / \mathrm{ml}$ ). The difference between TNM stage II and III is $365 \pm 34.6 \mathrm{ng} / \mathrm{ml}$ versus $407.4 \pm 21.8 \mathrm{ng} / \mathrm{ml}$. Using the cut-off value $\geq 161.5 \mathrm{ng} / \mathrm{ml}$, the researchers found that the serum chemerin showed $100 \%$ sensitivity and $100 \%$ specificity for CRC [8]. The selection of patients for the control group was similar to ours, although diabetes patients were excluded. In another study, no correlation was found with TNM staging $(\mathrm{p}=0.063)$ [7]. In addition, Eichelmann et al. [9] demonstrated that the risk of CRC in patients with elevated serum values is greater for the colon than for the rectum and greater still for the proximal segment of the colon. In our study, we did not find any significant differences between tumours in the initial stage of development and locally advanced tumours without metastases, i.e. between TNM stage II (IIA, IIB) and III (IIIA, IIIB, IIIC) in serum and saliva $(\mathrm{p}=0.82$ and $\mathrm{p}=0.52)$.

Numerous epidemiological studies show a positive correlation between obesity and an increased risk of colorectal, breast, ovarian, prostate, and endometrial cancer [4]. Earlier studies on larger groups of patients showed that chemerin is correlated with BMI, waist circumference, diet, insulin resistance, blood pressure and circulating triglycerides. However, this effect was not as pronounced compared to carcinogenesis $[6,15,16,17]$. In our study, in the subgroups with a BMI above and below 25 , we found no significant differences in the concentrations of the tested adipokine in groups $\mathrm{K}$ and $\mathrm{B}$. Height, body weight and BMI did not affect the results. Hence, no correlation was found in the subgroups of group B with the TNM classification.

It appears that the lack of correlation between the TNM classification and chemerin concentrations as well as the 
Table IV. Serum and saliva chemerin concentrations in groups $\mathrm{K}$ and $\mathrm{B}$ Tabela IV. Stężenia chemeryny w surowicy i ślinie grup K i B

\begin{tabular}{|c|c|c|c|c|c|c|c|}
\hline \multirow{2}{*}{ Variable } & \multicolumn{3}{|c|}{ K } & \multicolumn{3}{|c|}{ B } & \multirow{2}{*}{$p$} \\
\hline & Median & Q1 & Q3 & Median & Q1 & Q3 & \\
\hline Serum chemerin concentration (ng/ml) & 170.53 & 164.92 & 177.38 & 384.36 & 298.16 & 474.05 & 0.00 \\
\hline Saliva chemerin concentration (ng/ml) & 4.57 & 2.90 & 5.29 & 15.45 & 10.21 & 20.07 & 0.00 \\
\hline
\end{tabular}

Table Va. Correlation of serum and saliva chemerin concentrations in group $K$ subgroups with $B M I<25$ and $B M I \geq 25$ Tabela Va. Korelacja stężeń chemeryny w surowicy i ślinie w podgrupach K z BMI < 25 i BMI $\geq 25$

\begin{tabular}{|c|c|c|c|c|c|c|c|}
\hline \multirow{2}{*}{ Variable } & \multicolumn{3}{|c|}{$\mathrm{BMI}<25$} & \multicolumn{3}{|c|}{$\mathrm{BMI} \geq 25$} & \multirow{2}{*}{ p } \\
\hline & Median & Q1 & Q3 & Median & Q1 & Q3 & \\
\hline Serum chemerin concentration ( $\mathrm{ng} / \mathrm{ml}$ ) & 169.43 & 164.92 & 174.38 & 172.39 & 165.41 & 178.31 & 0.45 \\
\hline Saliva chemerin concentration (ng/ml) & 3.46 & 2.45 & 5.11 & 4.88 & 4.11 & 5.61 & 0.14 \\
\hline
\end{tabular}

Table Vb. Correlation of serum and saliva chemerin concentrations in group B subgroups with $\mathrm{BMl}<25$ and $\mathrm{BMI} \geq 25$ Tabela Vb. Korelacja stężeń chemeryny w surowicy i ślinie w podgrupach B z BMl < 25 i BMI $\geq 25$

\begin{tabular}{ccccccccc}
\hline \multirow{2}{*}{ Variable } & \multicolumn{3}{c}{ BMI $<25$} & \multicolumn{3}{c}{ BMI $\geq 25$} & p \\
\cline { 2 - 7 } & Median & Q1 & Q3 & Median & Q1 & Q3 & \\
\hline Serum chemerin concentration $(\mathrm{ng} / \mathrm{ml})$ & 417.25 & 298.16 & 496.71 & 312.84 & 276.51 & 474.05 & 0.54 \\
Saliva chemerin concentration $(\mathrm{ng} / \mathrm{ml})$ & 15.41 & 11.29 & 16.59 & 17.65 & 9.75 & 21.08 & 0.88 \\
\hline
\end{tabular}

Table Vla. Correlation of stage II and III of TNM tumour classification with serum and saliva chemerin concentrations Tabela Vla. Korelacja klasyfikacji II i lll stopnia zaawansowania guza wg TNM ze stężeniem chemeryny w surowicy i ślinie

\begin{tabular}{lccccccc}
\hline \multirow{2}{*}{ Variable } & \multicolumn{9}{c}{ II } & \multicolumn{1}{c}{ III } & \multirow{2}{*}{ p } \\
\cline { 2 - 7 } & Median & Q1 & Q3 & Median & Q1 & Q3 & \\
\hline Serum chemerin concentration $(\mathrm{ng} / \mathrm{ml})$ & 384.36 & 306.57 & 496.71 & 384.69 & 282.75 & 473.08 & 0.52 \\
Saliva chemerin concentration $(\mathrm{ng} / \mathrm{ml})$ & 16.18 & 10.21 & 20.07 & 14.89 & 10.36 & 19.95 & 0.82 \\
\hline
\end{tabular}

Table Vlb. Correlation of tumour in left colon $(L)$, right colon and rectum $(P)$ with serum and saliva chemerin concentrations Tabela VIb. Korelacja lokalizacji guza lewej części okrężnicy (L) i prawej części okrężnicy z odbytnica (P) ze stężeniem chemeryny w surowicy i ślinie

\begin{tabular}{cccccccc}
\hline \multirow{2}{*}{ Variable } & \multicolumn{4}{c}{ L } & \multicolumn{5}{c}{$\mathbf{R}$} & p \\
\cline { 2 - 8 } & Median & Q1 & Q3 & Median & Q1 & Q3 & \\
\hline Serum chemerin concentration $(\mathrm{ng} / \mathrm{ml})$ & 384.10 & 302.54 & 496.71 & 407.35 & 271.42 & 473.08 & 0.82 \\
Saliva chemerin concentration $(\mathrm{ng} / \mathrm{ml})$ & 16.46 & 10.21 & 21.08 & 13.83 & 10.17 & 17.15 & 0.18 \\
\hline
\end{tabular}

lack of correlation with the examined anthropometric indices results, among others, from the small number of studied patients. When analysing our and other control groups in studies on chemerin, patients with IBD and/or other inflammatory diseases were excluded. Serum chemerin levels are also increased in many inflammatory diseases, including IBD. Nonetheless, when comparing concentrations of chemerin in IBD with CRC, the latter values were significantly higher than in IBD; hence, it seems that they will not distort the results in the case of extensive research on the use of chemerin as an early diagnostic marker of CRC $[7,12,15]$. Notwithstanding, higher serum chemerin concentrations are not only associated with carcinogenesis but also with age, metabolic syndromes, obesity, insulin resistance, and inflammatory diseases. In the case of high concentrations in
$\mathrm{CRC}$, the influence of these factors on the results does not appear to be very significant $[7,9]$.

The compared group of CRC patients was characterised by a lower blood haemoglobin concentration compared to group K. Anaemia is a frequent symptom of CRC, especially if the right colon is affected. The compared commonly used marker - the carcinoembryonic antigen (CEA) is used primarily to detect cancer recurrence after colorectal surgery. This marker is not CRC specific and has limited clinical use. In our study, the median in patients in group B significantly increased, but since CEA is much less sensitive to the early stages of the disease and the sensitivity and specificity of this marker are too low, it is unfortunately not used for early diagnosis of CRC [18]. The groups did not differ significantly in the number of white blood cells. Still, 
a clear increase in the neutrophil count and decrease in lymphocyte count were observed in group B ( $p<0.000$, $\mathrm{p}=0.01)$ and the associated statistically significant differences in NLR and PLR indices $(p<0.000, p=0.02)$, but PLR was not affected by a small, statistically insignificant increase in the platelet count. The process of carcinogenesis is associated with different activities of neutrophils and lymphocytes. Neutrophilia and lymphopenia are associated with bacterial infections, some chronic diseases and tumours $[19,20]$. Research is being conducted on changes in the bacterial intestinal flora in CRC to explain the relationship of microbiota with the status of the immune system, chronic intestinal inflammation and cancer development.

In oncology, attempts are being made to use saliva to determine the concentration of markers of some types of cancer, including oral, colorectal, gastric, breast, and ovarian cancer $[21,22,23,24]$.

In the last decade, saliva testing has increasingly replaced some routine diagnostic tests. There are several advantages to this approach, including the ease of obtaining the test material, the possibility of repeated daily collection, the easy acceptance of a painless test and better analysis of the concentration of substances whose levels are affected by the stress of blood collection. Under certain conditions, an examination of saliva could replace a serum test, especially in patients with contraindications or impediments to blood collection. The replacement of serum tests in patients with saliva tests, in addition to the possibility of frequent repetitions accepted by the patient, is associated with lower test costs [24].

\section{CONCLUSIONS}

To sum up, chemerin can be a valuable CRC biomarker. A simple saliva and/or serum chemerin concentration test can support early diagnosis of CRC. The influence of BMI on the results seems to be insignificant in CRC patients. Nevertheless, the relationship between chemerin and cancer is not yet fully understood, nor its diagnostic significance; therefore research on this adipokine will continue.

\section{Author's contribution}

Study design - D. Waniczek, E. Świętochowska

Data collection - D. Waniczek, E. Świętochowska

Data interpretation - D. Waniczek, E. Świetochowska, Z. Lorenc

Statistical analysis - D. Waniczek

Manuscript preparation - D. Waniczek, E. Świętochowska

Literature research - D. Waniczek, E. Świętochowska, Z. Lorenc

\section{REFERENCES}

1. Ferlay J., Shin H.R., Bray F., Forman D., Mathers C., Parkin D.M. Estimates of worldwide burden of cancer in 2008: GLOBOCAN 2008. Int. J. Cancer $2010 ; 127(12): 2893-2917$, doi: $10.1002 /$ ijc. 25516.

2. Calle E.E., Rodriguez C., Walker-Thurmond K., Thun M.J. Overweight, obesity, and mortality from cancer in a prospectively studied cohort of U.S. adults. N. Engl. J. Med. 2003; 348(17): 1625-1638, doi: 10.1056/NEJMoa021423.

3. Donohoe C.L., O'Farrell N.J., Doyle S.L., Reynolds J.V. The role of obesity in gastrointestinal cancer: evidence and opinion. Therap. Adv. Gastroenterol 2014; 7(1): 38-50, doi: 10.1177/1756283X13501786.

4. Chamberland J.P., Berman R.L., Aronis K.N., Mantzoros C.S. Chemerin is expressed mainly in pancreas and liver, is regulated by energy deprivation, and lacks day/night variation in humans. Eur. J. Endocrinol. 2013; 169(4): 453-462, doi: 10.1530/EJE-13-0098

5. Kumar J.D., Holmberg C., Kandola S., Steele I., Hegyi P., Tiszlavicz L. et al. Increased expression of chemerin in squamous esophageal cancer myofibroblasts and role in recruitment of mesenchymal stromal cells. PLoS One 2014; 9(7): e104877, doi: 10.1371/journal.pone.0104877.

6. Bozaoglu K., Bolton K., McMillan J., Zimmet P., Jowett J., Collier G. et al. Chemerin is a novel adipokine associated with obesity and metabolic syndrome. Endocrinology 2007; 148(10): 4687-4694, doi: 10.1210/en.2007-0175. 7. Erdogan S., Yilmaz F.M., Yazici O., Yozgat A., Sezer S, et al. Inflammation and chemerin in colorectal cancer. Tumour Biol. 2016; 37(5): 6337-6342, doi 10.1007/s13277-015-4483-y

8. Alkady M.M., Abdel-Messeih P.L., Nosseir N.M. Assessment of serum levels of the adipocytokine chemerin in colorectal cancer patients. J. Med. Biochem. 2018; 37(3): 313-319, doi: 10.1515/jomb-2017-0062.

9. Eichelmann F., Schulze M.B., Wittenbecher C., Menzel J., Weikert C., di Giuseppe R. et al. Association of chemerin plasma concentration with risk of colorectal cancer. JAMA Netw. Open 2019; 2(3): e190896, doi: 10.1001/jamanetworkopen.2019.0896.
10. Wang C., Wu W.K., Liu X., To K.F., Chen G.G., Yu J. et al. Increased serum chemerin level promotes cellular invasiveness in gastric cancer: a clinical and experimental study. Peptides 2014; 51: 131-138, doi: 10.1016/j.peptides.2013.10.009

11. Xu C.H., Yang Y., Wang Y.C., Yan J., Qian L.H. Prognostic significance of serum chemerin levels in patients with non-small cell lung cancer. Oncotarget 2017; 8(14): 22483-22489, doi: 10.18632/oncotarget.14956.

12. Weigert J., Obermeier F., Neumeier M., Wanninger J., Filarsky M., Bauer S. et al. Circulating levels of chemerin and adiponectin are higher in ulcerative colitis and chemerin is elevated in Crohn's disease. Inflamm. Bowel Dis. 2010; 16(4): 630-637, doi: 10.1002/ibd.21091.

13. Du X.Y, Zabel B.A., Myles T., Allen S.J., Handel T.M., Lee P.P. et al. Regulation of chemerin bioactivity by plasma carboxypeptidase N, carboxypeptidase B (activated thrombin-activable fibrinolysis inhibitor), and platelets. J. Biol. Chem. 2009; 284(2): 751-758, doi: 10.1074/jbc.M805000200.

14. Lehrke M., Becker A., Greif M., Stark R., Laubender R.P., von Ziegler F. et al. Chemerin is associated with markers of inflammation and components of the metabolic syndrome but does not predict coronary atherosclerosis. Eur. J. Endocrinol. 2009; 161(2): 339-344, doi: 10.1530/EJE-09-0380.

15. Tan B.K., Chen J., Farhatullah S., Adya R., Kaur J., Heutling D. et al. Insulin and metformin regulate circulating and adipose tissue chemerin. Diabetes 2009; 58(9): 1971-1977, doi: 10.2337/db08-1528.

16. Bozaoglu K., Segal D., Shields K.A., Cummings N., Curran J.E., Comuzzie A.G. et al. Chemerin is associated with metabolic syndrome phenotypes in a Mexican-American population. J. Clin. Endocrinol. Metab. 2009; 94(8): 3085-3088, doi: 10.1210/jc.2008-1833.

17. Weigert J., Neumeier M., Wanninger J., Filarsky M., Bauer S., Wiest R. et al. Systemic chemerin is related to inflammation rather than obesity in type 2 diabetes. Clin. Endocrinol. 2010; 72(3): 342-348, doi: 10.1111/j.1365-2265. 2009.03664.x. 
18. Su B.B., Shi H., Wan J. Role of serum carcinoembryonic antigen in the detection of colorectal cancer before and after surgical resection. World J. Gastroenterol. 2012; 18(17): 2121-2126, doi: 10.3748/wjg.v18.i17.2121.

19. Bowen R.C., Little N.A., Harmer J.R., Ma J., Mirabelli L.G., Roller K.D. et al. Neutrophil-to-lymphocyte ratio as prognostic indicator in gastrointestinal cancers: a systematic review and meta-analysis. Oncotarget 2017; 8(19): 32171-32189, doi: 10.18632/oncotarget.16291

20. Tan D., Fu Y., Su Q., Wang H. Prognostic role of platelet-lymphocyte ratio in colorectal cancer: A systematic review and meta-analysis. Medicine 2016; 95(24): e3837, doi: 10.1097/MD.0000000000003837.
21. Pfaffe T., Cooper-White J., Beyerlein P., Kostner K., Punyadeera C. Diagnostic potential of saliva: current state and future applications. Clin. Chem. 2011; 57(5): 675-687, doi: 10.1373/clinchem.2010.153767.

22. Liu J., Duan Y. Saliva: a potential media for disease diagnostics and monitoring. Oral. Oncol. 2012; 48(7): 569-577, doi: 10.1016/j.oraloncology.2012.01.021.

23. Mizukawa N., Sugiyama K., Fukunaga J., Ueno T., Mishima K., Takagi S., Sugahara T. Defensin-1, a peptide detected in the saliva of oral squamous cell carcinoma patients. Anticancer Res. 1998; 18(6B): 4645-4649.

24. Lokesh K., Jayanthi K. Saliva: A mirror to health. Int. J. Contemp. Dent. Med. Rev. 2015: 1-3. 